6 J. Queiroz-Sousa ${ }^{* 1,2}$, S. A. Keith ${ }^{2,3}$, G. S. David ${ }^{4}$, H. Brandão ${ }^{5}$, A. B. Nobile ${ }^{1}$, J. V. K. Paes ${ }^{1}$,

7 A. C. Souto ${ }^{1}$, F. P. Lima ${ }^{1}$, R. J. Silva ${ }^{1}$, R. Henry ${ }^{1}$ and K. Richardson ${ }^{2}$

$8 \quad{ }^{1}$ Institute of Biosciences, São Paulo State University, Botucatu, Brazil.

SPECIES RICHNESS AND FUNCTIONAL STRUCTURE OF FISH ASSEMBLAGES IN THREE FRESHWATER HABITATS: EFFECTS OF ENVIRONMENTAL

\section{FACTORS AND MANAGEMENT}

${ }^{2}$ Center for Macroecology, Evolution and Climate, Natural History Museum of Denmark, Univ. of Copenhagen, Universitetsparken 15, DK-2100 Copenhagen, Denmark, ${ }^{3}$ Lancaster Environment Centre, Lancaster University, Lancaster, LA1 4YQ, UK

${ }^{4}$ Agencia Paulista de Tecnologia do Agronegócio (APTA), Jaú, São Paulo, Brazil. ${ }^{5}$ Paraná Federal Technology University, Santa Helena, Brazil.

Funding Information: Coordenação de Aperfeiçoamento Pessoal de Nível Superior (CAPES): (AUX-PE-PNPD 3005/2010) (BEX-PDSE 2574/2014-4)

\footnotetext{
* Correspondence: J. Queiroz-Sousa, Institute of Biosciences, São Paulo State University, Botucatu, SP, Brazil. Prof. Dr. Antônio Celso Wagner Zanin street, 250. Postal Code: 18618689 - Botucatu, SP, Brazil. Tel.: +55 143880 0637. E-mail: queiroz.jam@gmail.com
} 
Anthropogenic actions can facilitate the top-heaviness of trophic levels through the

21 introduction of novel consumers. In this present study, the inverted trophic hypothesis was tested in the freshwater fish comunities of reservoir. The distribution of fish species in three freshwater habitats in the Jurumirim Reservoir, Brazil, was examined using both species richness and the relative proportions of different trophic groups. These groups were used as a proxy for functional structure in an attempt to test the ability of these measures to assess fish diversity. Assemblage structures were first described using non-metric multidimensional scaling (NMDS). The influence of environmental conditions for multiple fish assemblage response variables (richness, total abundance and abundance per trophic group) was tested using Generalized Linear Mixed Models (GLMMs). The metric typically employed to describe diversity, i.e., species richness, was not related to environmental conditions. However, absolute species abundance was relatively well explained with up to $54 \%$ of the variation in the observed data accounted for. Differences in the dominance of trophic groups were most apparent in response to the presence of introduced fish species: the iliophagous and piscivorous trophic groups were positively associated, while detritivores and herbivores were negatively associated, with the alien species. This suggests that monitoring functional diversity might be more valuable than species diversity for assessing effects of disturbances and managements policies on the fish community.

Keywords: mixed effects models, nutrients, reservoir, sedimentation, trophic level. 
44 There is increasing recognition (e.g. UN Convention on Biological Diversity) of a need for 45 the management of the impacts of human activities on the abundance and distribution of the 46 non-human organisms in the environment. Such management requires an understanding of 47 the factors controlling the distributions of species (biodiversity) in nature. Traditionally, the baseline for assessing biodiversity has been metrics related to species richness (e.g., Chaudhary et al., 2016; Pianka, 1966; Tittensor et al., 2010). The main problem of assessing 50 taxonomic diversity alone is the fact that the species is only one unit against a set of all the 51 characteristic, functional and genetic variations that ultimately control the ecological functions (Griggs et al., 2013). More recently, however, the need to consider the functional diversity of the biosphere has been highlighted (Steffen et al., 2015) and a number of studies

54 have turned attention to the assessment of the "functional" structure of ecosystems (e.g.

55 Austen et al., 1994; Noble et al., 2007). The benefit of the functional aspects over the

56 taxonomic diversity indexes is the use of groups with functionally similar species (functional 57 groups) that occupy similar adaptive zones (Stanley, 1979) - although they are geographically and evolutionarily distinct. The functional groups can predict the outcome of interspecific interactions and interpret patterns in the community structure (Steneck and Watling, 1982).

60 Another motive for use of functional structure analysis is that anthropic actions have a major 61 impact on community biomass distributions (McCauley et al., 2018). The optical of the loss of diversity richness cannot explain it. The descriptions of biomass and abundance distributions in trophic boundaries and within communities helps elucidate fundamental mechanisms that shape the architecture of ecological communities (McCauley et al., 2018).

65 In this study, the distribution of fish species in the Jurumirim Reservoir, Brazil, was 
examined using both traditional biodiversity indices (species richness) and the relative dominance of different trophic feeding groups as a proxy for the functional structure of the assemblage in an attempt to assess the applicability of these two measures in the assessment of the fish biodiversity.

The Jurumirim Reservoir consists of heterogeneous environments both in terms of structure and dynamics, for example, distinct lacustrine and riverine zones (Henry, 2014). Lacustrine sites are characterised by deep water, a vertically stratified water column and limited nutrient availability in the well-lit surface waters, which keeps primary production at a relatively low level (Zanata and Espíndola, 2002). Riverine sites, located in the tributaries, are usually limited in transparency of water, i.e. sediment transport processes in these areas are affected by water flow, erosion and rains; and also have relatively low primary productivity (Wetzel, 2001). Marginal lagoons, located alongside the river channel, represent lentic waters with high rates of primary productivity and sediment deposition (Henry, 2014). Reservoir, tributary, and marginal lagoon, in combination, represent a large range of environmental variability (Franklin 2010; Hartley et al., 2010). They can be well suited for elucidating studies about habitat-filtering and species-sorting (Vanschoenwinkel et al., 2010; Erös et al., 2017), while fish species and community composition can be analysed in relation to environmental parameters (O'Sullivan and Reynolds, 2004; Thornton et al., 1990; Wetzel, 2001). These parameters are ideal for discerning the ecological "preferences" of the ichthyofauna, which are potentially exposed to distinct ranges of environments reflected in different community compositions and relative abundances. In other words, the fish are not simply found in a specific environment because they had no other choice of environment. 
The reservoir examined in this study was created following the construction of a dam in the middle of the $20^{\text {th }}$ Century. The changing habitat conditions following creation of the

94 dam led to changes in fish distributions in the period immediately following dam construction. Since 1974, the Upper Paranapanema basin has been classified as having excellent water quality and resources when compared to other basins within industrial or agriculture regions in Brazil (Carvalho, 2009), which means it offers an interesting study system in which to explore variation in functional structure in relation to environmental conditions. Over the past three decades, the intensity of fishing, the fish stocking, the fish cage farming and the introduction of non-native species have promoted changes in the fish composition, although physical conditions in the reservoir system have remained essentially unchanged (Nogueira et al., 2014). Fishing in Jurumirim Reservoir had been represented by a little subsistence and sport fishing, the latter being related to tourism in the area (Novaes and Carvalho, 2009). The intensity of fishing in the reservoir was previously estimated at $15.7 \mathrm{~kg}$ $\mathrm{ha}^{-1}$ year $^{-1}$ with CPUE values estimated at $10.5 \mathrm{~kg}_{\text {fisherman }}^{-1}$ day $^{-1}$ (Novaes and Carvalho, 2009; Schork et al., 2013). The increase of fish cage farming in Jurumirim is estimated at $2460 \mathrm{t} \mathrm{yr}^{-1}$, considering the current rate of production and growth potential relative to new aquaculture parks, in which the Nile tilapia Oreochromus nilotucus (L. 1758) is the main farmed species (Montanhini et al., 2015). Data on intentional fish stocking indicate 7,102,057 individuals belonging to six non-native fish species (Astronotus crassipinnis (Heckel 1840), Cyprinus carpio Linnaeus 1758, Sorubim lima (Bloch and Schneider 1801), Schizodon borellii (Boulenger 1900), Triportheus angulatus (Spix and Agassiz 1829), O. niloticus, and Hoplias lacerdae Miranda Ribeiro 1908) were released into the reservoir between 1978 and 1992 (Garcia et al., 2017). 
117 variety of purposes, i.e. enhancement of sport fishing, aquaculture, stock management and to 118 support an aquarium trade. Yellow tucunare Cichla kelberi Kullander and Ferreira 2006 has 119 been illegally released for sport fishing. This species is generally piscivorous and potentially 120 influences ecosystems by increasing the predation pressure on lower trophic levels (Santos et al., 1994). Oreochromus nilotucus has escaped from aquaculture facilities. This species normally occupies lower trophic levels and can influence ecosystems through changes in

123 primary production and water transparency (Vitule et al., 2009). These two species are 124 examples of the fact that the functional types (sizes, dietary preferences, etc.) of introduced

125 fish species can be quite different and can have distinct influences on ecosystems and the 126 diversity of native fish (Latini and Petrere, 2004; Pelicice and Agostinho, 2009; Vitule et al., 127 2009).

These anthropogenic actions can facilitate the top-heaviness of trophic levels through

129 the introduction of novel consumers (McCauley et al., 2018). Piscivores and detritivores

130 could be dominant in the reservoir as a whole, while herbivores could dominate in the

131 riverine habitat. Thus, it is expected that the proportion of upper trophic levels is higher in

132 the reservoir than in the riverine habitat, demonstrating a trophic inversion in the fish

133 comunities. Some studies have reported inverted trophic pyramids or inverted trophic

134 biomass pyramids for fish groups (McCauley et al., 2018 and references therein). In this

135 present study, the inverted trophic hypothesis was tested in the freshwater fish comunities of 136 reservoir. The relative proportion of fish feeding at high and low trophic levels would differ 137 in the different habitats of Jurumirim Reservoir and that the proportion of fish from high/low 138 trophic levels would be influenced by the physical conditions in the reservoir and by the 139 presence of alien species. The aims of this study were to describe the distribution of the fish 140 communities: 1) comparing communities in the different habitat types through NMDS and 2) 
141 explaining these differences by analysing the effects of environmental and anthropogenic

142 gradients.

\section{MATERIAL AND METHODS}

STUDY AREA

150 The dam for the Jurumirim Hydroelectric Plant was built on the upper Paranapanema River

151 in the late 1950s near the convergence of the Paranapanema and Taquari Rivers (Carvalho, 152 2009). The associated Jurumirim Reservoir, which is under state protection, is fed by ten 153 tributaries and has a flooded area of $484 \mathrm{~km}^{2}$ with a perimeter of $1,115 \mathrm{~km}$. Its total water 154 volume is 7.2 billion $\mathrm{m}^{3}$ and it has a mean depth of $12.90 \mathrm{~m}$ (maximum $40 \mathrm{~m}$ ), with a 155 drainage area of approximately $17,800 \mathrm{~km}^{2}$. Twenty-eight municipalities are situated within 156 the watershed of the basin with a combined population of over 2.5 million inhabitants 157 (Nogueira et al., 1999). Therefore, this area is of high importance for providing ecosystem services to the local region, for example, hydropower, quantity and quality of clean water, 159 food supply and recreation potential.

\section{DATA COLLECTION AND PREPARATION}

164 Fish and environmental samples were collected at 13 sites throughout the Jurumirim reservoir 165 system (Fig. $1 ; 23^{\circ}-24^{\circ} \mathrm{S} / 48^{\circ}-49^{\circ} \mathrm{W}$ ) every three months from April 2011 to January 2013, 
generating a total of 104 sample sets. Sites were selected to represent the heterogeneity of

167 limnological habitats found in the reservoir system. Another condition used in site selection

168

169

170

171

172

173

174

175

176

177

178

179

180

181

182

183

184

185

186

187

188

189

190

77

was that the sites should meet the requirements for effective and reliable gillnet capture.

Environmental conditions monitored at these sites included physical and chemical properties, nutrient concentrations and the characterization of bottom sediments (see full list in Table S1). Temperature, conductivity, dissolved oxygen, nutrients and chlorophyll concentration were measured at a depth of 1 meter. Fish gillnets were retrieved after a fishing period of 18 hours. Catches were identified and weighed following the taxonomy of Graça and Pavanelli (2007). Based on these data, species richness and total number of individuals were calculated for each site (Krebs, 1989).

In order to explore the functional structure of the species assemblages, each species was assigned to a trophic group according to the following trophic categories: detritivorous (Mérona and Rankin-de-Mérona, 2004), herbivorous (Castro, 1997) insectivorous, piscivorous (Williams et al., 1998), omnivorous (Mérona and Rankin-de-Mérona, 2004), and iliophagous (i.e., a diet of microorganisms and organic matter within muddy substrate, Hahn et al., 1998). The digestive tract of each captured fish was examined and the stomach contents were analysed using a stereo- and an optic microscope. Food items were weighed and classified according to the Alimentary Index (AI\%) proposed by Kawakami \& Vazzoler (1980), following the equation: $\mathrm{AI} \%=\mathrm{F}_{\mathrm{i}} \mathrm{W}_{\mathrm{i}} \mathrm{x} 100 \mathrm{x} / \Sigma \mathrm{F}_{\mathrm{i}} \mathrm{x} \mathrm{W} i$, where: $\mathrm{AI}=$ food index; $\mathrm{i}=$ $1,2 \ldots n$, food, $F_{i}=$ frequency of occurrence of item $\mathrm{i}(\%) ; \mathrm{W}_{\mathrm{i}}=$ wet weight of item $\mathrm{i}(\%)$. The dominant group of food items (highest AI\%) was used to define the trophic group for all species for which this study had a sample size of at least four individuals $(60 \%$ of the species). For the $40 \%$ of species with too few samples ( $<$ four individuals with stomach 
contents) to establish the trophic group from gut contents, trophic group classification was based on published data (published before March 8th 2019 e.g., journal articles, university theses, books and FishBase - Table S2).

194

STATISTICAL ANALYSIS

In order to describe the similarity in fish assemblages among the sites visually, Non-Metric Multidimensional Scaling (NMDS) was used in two dimensions with 999 permutations. This allowed us to find the optimal placement of sites and species, so that the more similar two species assemblages are, the closer the sites are the in two-dimensional plot of the NMDS (Oksanen 2015). Similarity was calculated from the species composition data using BrayCurtis distance because it is robust with respect to bias induced by differences in sampling effort (Faith et al., 1987). Sites that were most similar to one another in species composition are closest together on the NMDS plot (Fig.2; Oksanen et al., 2015). structure in reservoirs was tested by comparing the ratios of the distributions of biomass and

210 the abundance of fishes occupying "higher" and "lower" trophic levels, where predatory and

211 detritivorous fish species (piscivorous, omnivorous and detritivorous), were defined as eating

212 at the higher trophic levels. Fish belonging to the remaining groups (herbivores, iliophages

213 and insectivores) were considered to be eating at lower trophic levels. Ratios approaching 1

214 indicate a balanced distribution in the community between higher and lower trophic groups. 
215 The fish trophic levels ratio across different habitat types were compared using the Kruskal-

216 Wallis test.

217

218

219

220

221

222

223

224

225

226

227

228

229

230

231

232

233

234

235

236

237

238

Based on previous analyses that identified important environmental conditions for predicting fish species richness and abundance (Griffiths, 2011), 11 abiotic variables from the set of 21 variables collected were selected as predictors (Table I). Broadly speaking, these variables represent changes in limnological conditions associated with damming. Using them therefore enables us to identify the importance of limnological gradients for determining species assemblages. Because the presence of non-native fish species can strongly influence the structure of resident fish assemblages (e.g., Britton and Orsi, 2012; Vitule et al., 2009), the presence of $C$. kelberi, the jewel tetra Hyphessobrycon eques (Steindachner 1882), the silver dollar Metynnis maculatus (Kner 1858), O. nilotucus, the catfish Pterygoplichthys ambrosetti (Holmberg 1893) or the red-breasted tilapia Coptodon rendalli Boulenger 1897 was also included as a binary predictor variable (Table S2). determine the potential for these variables to predict multiple aspects of the assemblage species richness, abundance of individuals across all species, and abundance of individuals within trophic groups - resulting in eight models. Month and site were included as random effects to account for spatial and temporal autocorrelation (Zuur et al., 2009). To meet the conditions of multiple regression, data were checked for normality and homogeneity of variance, and then transformed with $\log (\mathrm{x}+1)$. Outliers were checked for using Cook's distance for each variable (Logan, 2011); the outliers were deleted so that the resulting data 
matrix had the same number of observations for each variable, but no outliers. To ease the comparison of coefficients among the predictor variables, those measured on a continuous scale were normalized to be centered at zero with a standard deviation of one (Bolker, 2008). Pearson and Spearman correlations were generated to test for multicollinearity of predictor

244 variables, which was considered problematic if $r>0.6$ (Bolker, 2008). In the case of collinearity, the variable presenting the clearest a priori biological meaning was included in the model while the other was excluded. All variables were tested for linear and quadratic relationships, and those with a quadratic variable that reduced the Bayesian Information Criterion $(\triangle \mathrm{BIC})$ by $>3$ in comparison with the linear model were included as quadratics. The full model included all biologically plausible interactions between factors.

Following model selection, models within $3 \Delta \mathrm{BIC}$ of the top ranked model were considered equivalent and model-averaged (Burnham and Anderson, 2002; Bolker, 2008). Model averaging of this 'top model set' can provide a robust means of obtaining parameter estimates (both point and uncertainty estimates) and making predictions (Burnham and Anderson, 2002). Confidence intervals (95\%) were calculated for the model-averaged coefficients (Zuur et al., 2009). For testing the significance of the parameters, variables were defined as contributing significantly to the predictive model if their confidence intervals did not overlap zero. The variation in the data explained by random effects was considered as significant if 95\% confidence intervals for the estimated intercept for individual groups (i.e., months or sites) overlapped the mean intercept value (Figure S1). The marginal coefficient of determination $\left(\mathrm{R}^{2} \mathrm{GLMM}(m)\right)$, which indicates the variance explained by fixed factors, and conditional coefficient of determination $\left(\mathrm{R}^{2}{ }_{\mathrm{GLMM}}(c)\right)$, which indicates the variance explained

264 by both fixed and random factors (Nakagawa and Schielzeth, 2013), were estimated. If the 
265 values of $\mathrm{R}^{2}{ }_{\mathrm{GLMM}(c)}$ were equal to or less than $\mathrm{R}^{2}{ }_{\mathrm{GLMM}(m)}$, the random effects model was simplified to a GLM to minimise problems of over-parameterisation (Zuur et al., 2009).

267

268

All analyses were performed in R version 3.1.1 (R Development Core Team) with vegan (Oksanen et al., 2015), lme4 (Bates et al., 2012), Mumin (Bartoń, 2012), visreg (Breheny and Burchett, 2013), effects (Fox, 2003), car (Fox and Weisberg, 2011), plotrix

272 (Lemon, 2006) and ggplot2 (Wickham, 2009) packages.

273

\section{RESULTS}

276

277

278

The composition of fish assemblages grouped according to habitat type (lagoon, reservoir and river) when compared using the Bray-Curtis similarity metric, indicated by the proximity of sites in the NMDS plot (Figure 2). Species associated with river sites included the Cascarudo Callichthys callichthys (L. 1758), the catfishes Hypostomus ancistroides (Ihering 1911) and Hypostomus regani (Ihering 1905), the headstanders Leporinus octofasciatus Steindachner 1915 and Leporinus striatus Kner 1858, the three-barbeled catfish Rhamdia quelen (Quoy \&

284 Gaimard, 1824), the thorny catfish Rhinodoras dorbignyi (Kner 1855) and the golden dorado Salminus hilarii Valenciennes, 1850. All other species were more closely associated with dam and marginal lagoon sites, suggesting a preference amongst these species for lentic conditions. 

were locally restricted in their distributions. For example the characin Astyanax bockmanni Vari \& Castro 2007, the catfish Hypostomus nigromaculatus (Schubart 1964) and the pacu Piaractus mesopotamicus (Holmberg 1887) are omnivorous species that were not found in reservoir sites (Table S3). Similarly, the piscivorous C. kelberi and trahiras Hoplias intermedius (Günther 1864), the iliophagous catfish Hypostomus margaritifer (Regan 1908) and the omnivorous headstander Leporinus amblyrhynchus Garavello \& Britski 1987 were all absent from marginal lagoons and river sites (Table S3). omnivores and detritivores) were more strongly associated with the reservoir (mean $>1$ ), while communities dominated by lower trophic levels were associated with the river (mean $<$ 1) $(\mathrm{K}-\mathrm{W}$ test: chi-squared $=36.65, \mathrm{df}=7$, p-value $<0.001$; Fig. 3$)$. and site did not capture any additional variance in the data and therefore the species richness model was simplified to a GLM. In contrast, the total number of individuals was better

310 predicted, with $38 \%$ of the variation in the data explained by environmental conditions,

311 increasing to $54 \%$ with the inclusion of month and site as random effects $\left(\mathrm{R}^{2} \operatorname{GLMM}(m)=0.38\right.$,

$\left.312 \mathrm{R}^{2} \mathrm{GLMM}(c)=0.54\right)$. Specifically, the total abundance was predicted to decrease with increased

313 temperature, smaller sediment grain size, lower concentration of organic matter and

314 decreasing $\mathrm{pH}$ (Table II). Interactions among the predictor variables indicated that, with low 
concentrations of nitrogen and phosphorous, the number of individuals decreases with increasing chlorophyll a, while at high concentrations of these nutrients, the relationship switches to an increase in individuals with increasing chlorophyll a (Fig. 4a, b). The presence of non-native fish species did not contribute significantly in any of these models. important role in predicting the abundance of four of the six trophic groups: detrivores, herbivores, omnivores and piscivores (Table II). Across the models, the environmental conditions and the presence of non-native fish together explained $13 \%$ to $64 \%\left(\mathrm{R}^{2} \mathrm{GLMM}(\mathrm{m})\right)$ and, when random effects were also included, explained $35 \%$ to $89 \%\left(\mathrm{R}^{2} \mathrm{GLMM}(c)\right)$ of the variation in the data (Table II). The contribution of environmental predictors varied substantially among groups but all models included a significant contribution from at least one environmental predictor. Interactive effects between chlorophyll-a and nitrogen (Fig. 4d,f,h) and between temperature and nitrogen (Fig. 4c,e,g) were extremely weak, with large confidence intervals, so we will not discuss them further in this paper.

334 the variation in the data $\left(\mathrm{R}^{2}{ }_{\mathrm{GLMM}(m)}=0.64, \mathrm{R}^{2}{ }_{\mathrm{GLMM}(m)}=0,32, \mathrm{R}^{2}{ }_{\mathrm{GLMM}(m)}=0.31\right)$. Herbivores and detritivores had their habitat characterised by smaller sediment grain size and was less likely to harbour non-native fish. Detritivores were associated with water that was more saline (higher conductivity), more acidic (lower $\mathrm{pH}$ ), and lower in chlorophyll-a concentrations. Herbivores were primarily associating abundance with lower conductivity, higher $\mathrm{pH}$, more phosphorous and lower chlorophyll-a concentrations. Iliophagous species 
were specifically associated with higher temperatures and lower productivity, indicated by negative coefficients of phosphorous and organic matter, and tended to be found in sites with

342 non-native fish. Omnivores and piscivores were better predicted (omnivore $\mathrm{R}^{2}{ }_{\mathrm{GLMM}}(\mathrm{m})=$

3430.40 , piscivore $\left.\mathrm{R}^{2}{ }_{\mathrm{GLMM}(m)}=0.59\right)$ in habitats with smaller grain sizes but otherwise showing

344 little overlap in association. Piscivores were more likely to be found in waters with higher

345 likelihood for the presence of non-native fish (See Table II for coefficient values).

346 Insectivores were poorly predicted $\left(\mathrm{R}^{2}{ }_{\mathrm{GLMM}(m)}=0.13\right)$ by environmental conditions and the

347 presence of non-native fish; their only association was with less saline waters.

Including random effects in these models had different impacts across trophic groups.

Detritivore, insectivore and omnivore abundances were much better predicted by the inclusion of month and site, increasing the percent of variation explained by $23 \%, 22 \%$ and $49 \%$ respectively. Herbivore abundance was not improved at all by adding random effects, while amount of variation explained in the iliophage and piscivore abundance data was increased by $11 \%$ and $9 \%$ respectively.

\section{DISCUSSION}

361 This study presents species and community metrics comparing the lagoon, reservoir and

362 tributaries in the Jurumirim Reservoir. The results obtained by NMDS analysis suggest that 363 species are segregated into these different habitats. The results of the GLMM models

364 furthermore suggest trophic level is a more appropriate monitoring tool for describing 
ecological status than species richness. While no significant relationship was found between species richness and the abiotic factors considered here, trophic level did correlate with the different conditions. This suggests that more information relevant to understanding and describing the ecological status of the different fish communities in the reservoir system is contained in the trophic level metrics than in species richness. Specifically, differences in the relative abundances of fish were found (Fig. 3), highlighting different trophic structures among the different habitats identified. Predators from higher trophic niches and detritovores dominated in lentic habitats (reservoir), while fishes occupying lower trophic levels dominated in other habitats and thus, the inverted trophic hypothesis (McCauley et al., 2018) was supported.

.

\section{RELATIONSHIP BETWEEN FISH DISTRIBUTIONS AND ENVIRONMENTAL} PARAMETERS:

The interaction analyses reported indicate possible relationships between some environmental parameters and different fish groups. We consider here to what degree these relationships might be causal. When there is a pattern, we justified the distribution of trophic groups considering the variation of environmental parameters that respond quantitatively the anthropic actions, impoundment and fish introductions.

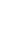

Total nitrogen concentration was found to be a better predictor of herbivorous, iliophagous and omnivorous fish than it was of phytoplankton biomass (chlorophyll-a 
concentration). As there is no a priori reason to expect total nitrogen to directly influence the abundance of these fish groups, it is assumed that high concentrations of total nitrogen serve here as a proxy for identifying habitats with a high abundance of organic material and/or high remineralization rates of nitrogen, i.e. conditions that would be attractive for all three trophic groups, which appeared to increase in habitats with high total nitrogen, i.e. typically lotic conditions (Table S1).

A decrease in iliophagous fish (but a slight increase in herbivores) was detected in relation to increased phosphorous concentrations. Generally, higher phosphorous concentrations were noted under river as compared to reservoir conditions. The release or uptake of phosphorous into the water column in the river channel is associated with biotic components of the system (periphyton and vascular plants) and bottom sediments (Correll, 1998). Once delivered to a reservoir, phosphorous is usually stored in the bottom sediments. The results of the current study are consistent with previous work which has shown that the phosphorous-fish relationship can be the result of changes occurring at the base of the food web (i.e., primary production) in response to changed nutrient conditions in an oligotrophic system (Karlsson et al., 2009), as in Jurumirim.

We found that not only the increase of conductivity is associated with sedimentation and reduced nutrient cycling (Dunlop et al., 2005) but also the $\mathrm{pH}$ and organic matter. With respect to the latter two parameters, the variations of values might be explained as being a consequence of the sedimentation in tributaries and the buffering nature of the reservoir. The

414 flow of water influences fluvial erosion, which promotes sedimentation (Henry, 2014). The 
415 deposition of fine sediment and organic matter in the lentic regions is greater than that in lotic

416 regions (Table S1). The deposition of fine sediment on the substrate in a habitat affects all

417 trophic levels. The river acidity levels were associated with sedimentation rates. However,

418 the differences in acidity were not high enough to affect the abundance of herbivorous and

419 omnivorous fish. In case of a more accentuated acidification, the phytoplankton biomass

420 could be low, which could led to a simplification of the zooplankton association, which, in

421 turn, could limit many fish species (Hendrey et al., 1976).

422

423

Piscivores and non-native fishes have earlier been reported, as was also observed in this study, to be dominant in deeper zones and in lentic environments (Matthews, 1998).

Non-native fishes was not a variable exclusively pertinent to piscivorous fishes. They may also be omnivorous, iliophagous and herbivorous. In case of the trophic interactions of native and introduced piscivorous fish, Fugi et al. (2008) noted coexistence between these groups.

429 They argued that this was due to prey and resource overlap being small between the introduced and the native species.

Iliophagous fish were found in our study to be more likely to coexist with non-native

434 fish than detritivores. The detritivorous and iliophagous categories were separated in the analysis because different factors may influence the feeding by grazers that live on algae and consumers of detritus (Bowen, 1984; Flecker, 1996). In the case of the relationship between

437 iliophagous and non-native fish in our study, however, the iliophagous fish are all represented 438 by loricariids with scutes and they are harder to prey upon than naked or scale-covered fish.

439 The occurrence of non-native fishes may be an important predictor of abundance and 
440 diversity of other species but the knowledge of potential effects of these non-native species is

441 still limited.

442

443

444 IMPLICATION FOR USING TROPHIC LEVELS AS A MEASURE OF STOCK

445 MANAGEMENT:

446

447

448

The Upper Paranapanema River basin has experienced the introduction of lacustrine species

449 through fish stocking (Miranda, 2001). Native and non-native fish stocking has occurred

450 since the 1980s in the Jurumirim Reservoir (CESP, 1996). Between 1999 and 2012, a Duke

451

Energy Company stocking program added more than 19 million young fish representing the

452

native species P. mesopotamicus, S. hilarii, Prochilodus lineatus (Valenciennes, 1837),

453

Leporinus friderici (Bloch, 1794), Leporinus obtusidens (Valenciennes, 1837), and Brycon

454

orbignyanus (Valenciennes, 1850) to the reservoirs and tributaries of the Paranapanema River

455

with the aim of building sustainable populations fully adapted to life in the river (Duke

456 Energy, 2013). It is shown by our study that, with the exception of B. orbignyanus (Fig 2),

457

these species are now widely distributed. L. friderici for example, was found in high

458

abundances in the reservoir, where most other herbivores were not as frequent. The success

459 of these populations might, therefore, be due to the stocking program. The non-native fish

460 stocking is not authorized; however introductions are still occurring. It is not by chance that our study denounces the occurrence of 6 species.

462

463

If a trophic level ratio metric becomes adopted as a management tool, it might be

464 possible to use the ratio to identify the trophic profile of species most likely to succeed in 
465

466

467

468

469

470

471

472

473

474

475

476

477

478

479

480

481

482

483

484

485

486

487

488

potential stocking initiatives in different areas. The choice of species for fish stocking programs should respect the habitat preferences of different trophic groups in order to avoid changing natural community structure. A fish index developed based on the distribution of different trophic levels might serve as a practical tool in relation to fish stock management for reservoirs with a similar range of environmental conditions as those in the range as in the Jurumirim reservoir system. However, the use of secondary data on trophic information of the fish species should be limited seeking local veracity due to the existence of a trophic plasticity. In our case, it was valuable to use data already published, since they would complement the information gap of the empirical analysis, being a literature with the area of study of the same hydrographic basin or approximations and the trophic plasticity occurring within the spectrum that defines each group.

The data presented here suggest that fish management in freshwaters (reservoirs and tributaries) should ideally be designed to deal with each habitat type individually. The trophic level (as a proxy for functional index) may be a more pratical and appropriate tool for monitoring the local fish communities when traditional species-based diversity metrics, for example species richness, do not respond. In this study, we found that a substantial portion of the variation in abundances of individuals and trophic groups was explained by environmental conditions or the presence/absence of alien fish species. Thus, the simple trophic metric describing the relative proportion of fish from the highest trophic levels in the community used here provides a useful tool for monitoring changes in the functional structure of the communities present. 
493 We thank Dr. J. A. Nienow as reviewer. This study was conducted as part of "The

494 environmental integrity of the Jurumirim reservoir" thematic project supported by

495 Coordenação de Aperfeiçoamento Pessoal de Nível Superior (CAPES). The authors also 496 thank the (CAPES) (AUX-PE-PNPD 3005/2010) (BEX-PDSE 2574/2014-4) for the scholarships granted and the staff of the Fish Biology and Ecology Laboratory and the Wild Animal Parasitology Laboratory, Biosciences Institute of Botucatu - Sao Paulo State University and Center for Macroecology, Evolution and Climate, Danish Natural History Museum, University of Copenhagen for providing the facilities necessary to carry out this study, and funding support from VILLUM FONDEN (S.A.K., grant no. 10114). The sampling program, including the capture of live fish, was reviewed and authorized by the animal ethics committee, SISBIO (Sistema de Autorização e Informação em Biodiversidade)

504 linked to IBAMA (Instituto Brasileiro do Meio Ambiente e dos Recursos Naturais

505 Renováveis), a Brazilian governmental entity that deals with environmental policies; the 506 SISBIO license has the registration number: 15549Q1.

507

508

509 Author contributions: This study was designed by JQ, HB, GS, RS and RH. Field and 510 laboratory data were obtained by JQ, HB, AN, JP, CS, FL and RS. JP, CS, FL conducted trophic analysis. JQ, HB, AN, JP and RS conducted limnological analysis. SK and KR contributed with the model's analysis. JQ, SK and KR conducted the statistical analyses. JQ,

513 SK, GS, RH and KR wrote the paper with input from all co-authors. 


\section{REFERENCES}

517

518

519 Austen D.J., Bayley P.B. \& Menzel B.W. (1994) Importance of the guild concept to fisheries research and management. Fisheries, 19, 12-20.

Bartón, K. (2014). R package "MuMIn": Multi-model inference (version 1.10. 5). URL

522 http://CRAN. R-project. org/package= MuMIn. (last accessed 6 September 2018).

Bates, D., Maechler, M., Bolker, B. \& Walker, S. (2014). lme4: Linear mixed-effects models using Eigen and S4. R package version, 1, 1-23.

525

Bolker, B. M. (2008). Ecological models and data in R. Princeton University Press.

Bowen, S. H. (1984). Detritivory in neotropical fish communities. In Evolutionary ecology of neotropical freshwater fishes, Vol. 3 (Zaret, T.M., ed), pp. 59-66. Springer Netherlands.

Breheny, P. \& Burchett, W. (2012). Visualizing regression models using visreg. Kentucky: Lexington.

Britton, J. R. \& Orsi, M. L. (2012). Non-native fish in aquaculture and sport fishing in Brazil: economic benefits versus risks to fish diversity in the upper River Paraná Basin. Reviews in Fish Biology and Fisheries, 22, 555-565.

533 Burnham, K. P. \& Anderson, D. R. (2003). Model selection and multimodel inference: a 534 practical information-theoretic approach. Springer Science \& Business Media.

535 Carvalho, E.D. (2009). Ações antrópicas e a biodiversidade de peixes: Status da represa de Jurumirim (Alto Paranapanema). "Livre-Docência” or Thesis for High-level Teaching in Brazil, University of São Paulo State, Botucatu, São Paulo, Brazil. http://www.ibb.unesp.br/Home/Departamentos/Morfologia/Laboratorios/LaboratoriodeB 
iologiaeEcologiadePeixes/livre-docencia-edmir---versao-completa.pdf (last accessed 6

$540 \quad$ September 2017).

541 Castro, R. M. (1997). The fish fauna from a small forest stream of the upper Paraná River

542 basin, southeastern Brazil. Ichthyological Exploration of Freshwaters, 7, 337-352.

543 CESP - Centrais Energéticas Do Estado De São Paulo (1996). Technical Report: Aspectos

544 limnológicos, ictiológicos e pesqueiros de reservatórios da CESP no período de 1986 a

545 1994. CESP Série pesquisas e desenvolvimento, São Paulo.

546 Chaudhary, C., Saeedi, H. \& Costello, M. J. (2016). Bimodality of latitudinal gradients in

547 marine species richness. Trends in Ecology \& Evolution, 31, 670-676.

548 Correll, D. L. (1998). The role of phosphorus in the eutrophication of receiving waters: a

549 review. Journal of Environmental Quality, 27, 261-266.

550 Duke Energy (2013). ABC da Energia: A história da Duke Energy no rio Paranapanema.

551 Relatório Anual de Administração, São Paulo.

552 Dunlop, J., McGregor, G. \& Horrigan, N. (2005). Characterization of impacts and a

553 discussion of regional target setting for riverine ecosystems in Queensland. The State of

$554 \quad$ Queensland.

555 Erős, T., Takács, P., Specziár, A., Schmera, D. \& Sály, P. (2017). Effect of landscape context

556 on fish metacommunity structuring in stream networks. Freshwater Biology, 62, 215-

557228.

558 Faith, D. P., Minchin, P. R. \& Belbin, L. (1987). Compositional dissimilarity as a robust

559 measure of ecological distance. Vegetatio, 69, 57-68.

560 Flecker, A. S. (1996). Ecosystem engineering by a dominant detritivore in a diverse tropical $561 \quad$ stream. Ecology, 77, 1845-1854.

562 Fox, J. (2003). Effect displays in R for Generalised Linear models. Journal of Statistical

563 Software, 8, 1-27. http://www.jstatsoft.org/v08/i15/. 
564 Fox, J. \& Weisberg, S. (2010). An R companion to applied regression. California: Sage.

565 Franklin, J. (2010). Mapping species distributions: spatial inference and prediction. New

$566 \quad$ York: Cambridge University Press.

567 Fugi, R., Luz-Agostinho, K. D. \& Agostinho, A. A. (2008). Trophic interaction between an

568 introduced (peacock bass) and a native (dogfish) piscivorous fish in a Neotropical

569 impounded river. Hydrobiologia, 607, 143.

570 Garcia, D.A.Z., Britton, J.R., Vidotto-Magnoni, A.P., \& Orsi, M.L. (2017). Introductions of

571 non-native fishes into a heavily modified river: rates, patterns and management issues in

572 the Paranapanema River (Upper Paraná ecoregion, Brazil). Biological Invasions, 1-13.

573 Golterman, H.L., Clyno, R.S. \& Ohsntad, M.A.M. (1978). Method for chemical analysis of

$574 \quad$ freshwater. Oxford: Blackwell.

575 Graça, W.J. \& Pavanelli, C.S., (2007). Peixes da planície de inundação do alto rio Paraná e

576 áreas adjacentes. Maringá: Eduem.

577 Griffiths, D. (2012). Body size distributions in North American freshwater fish: large-scale

578 factors. Global Ecology and Biogeography, 21, 383-392.

579 Griggs, D., Stafford-Smith, M., Gaffney, O., Rockström, J., Öhman, M.C., Shyamsundar, P., 580 Steffen, W., Glaser, G., Kanie, N. and Noble, I. (2013). Policy: Sustainable development 581 goals for people and planet. Nature, 495 (7441), 305- 307.

582 Hahn, N. S., Agostinho, A. A., Gomes, L. C. \& Bini, L. M. (1998). Estrutura trófica da 583 ictiofauna do reservatório de Itaipu (Paraná-Brasil) nos primeiros anos de sua formação. Interciência, 23, 299-305.

585 Hartley, S., Krushelnycky, P. D. \& Lester, P. J. (2010). Integrating physiology, population

586 dynamics and climate to make multi-scale predictions for the spread of an invasive

587 insect: the Argentine ant at Haleakala National Park, Hawaii. Ecography, 33, 83-94. doi: 
589 Hendrey, G. R., Baalsrud, K., Traaen, T. S., Laake, M., \& Raddum, G. (1976). Acid 590 precipitation: some hydrobiological changes. Ambio, 224-227.

591 Henry, R. (2014). Represa de Jurumirim: ecologia, modelagem e aspectos sociais. Ribeirão 592 Preto, SP: Holos.

593 Karlsson, J., Byström, P., Ask, J., Ask, P., Persson, L. \& Jansson, M. (2009). Light limitation 594 of nutrient-poor lake ecosystems. Nature, 460, 506.

595 Kawakami, E. \& Vazzoler, G. (1980). Método gráfico e estimativa de índice alimentar 596 aplicado no estudo de alimentação de peixes. Boletim do Instituto oceanográfico, 29, $597 \quad 205-207$.

598 Krebs, C.J. (1989). Ecological methodology. New York: Harper and Row.

599 Langeani, F., Macedo Corrêa e Castro, R., Takeshi Oyakawa, O., Akio Shibatta, O., Simone 600 Pavanelli, C. \& Casatti, L. (2007). Diversidade da ictiofauna do Alto Rio Paraná: 601 composição atual e perspectivas futuras. Biota Neotropica, 7.

602 Latini, A. O. \& Petrere, M. (2004). Reduction of a native fish fauna by alien species: an 603 example from Brazilian freshwater tropical lakes. Fisheries management and $604 \quad$ Ecology, 11, 71-79.

605 Lemon, J. (2006). Plotrix: a package in the red light district of R. R-news, 6, 8-12.

606 Logan, M. (2011). Biostatistical design and analysis using R: a practical guide. Oxford: John $607 \quad$ Wiley and Sons.

608 Matthews, W.J. (1998). Patterns in freshwater fish ecology. Dordrecht: Springer Science and 609 Business Media BV.

610 Mérona, B. D. \& Rankin-de-Mérona, J. (2004). Food resource partitioning in a fish 611 community of the central Amazon floodplain. Neotropical Ichthyology, 2, 75-84. 
612 Miranda, L.E. (2001). A review of guidance and criteria for managing reservoirs and 613 associated riverine environments to benefit fish and fisheries. In FAO fisheries technical $614 \quad$ paper, p91-138.

615 Montanhini, R. N., Nocko, H. R., \& Ostrensky, A. (2015). Environmental characterization 616 and impacts of fish farming in the cascade reservoirs of the Paranapanema River, Brazil. 617 Aquaculture Environment Interactions, 6, 255-272.

618 Noble, R.A.A., Cowx, I.G., Goffaux, D., \& Kestemont, P. (2007). Assessing the health of 619 European rivers using functional ecological guilds of fish communities: standardising 620 species classification and approaches to metric selection. Fisheries Management and 621 Ecology, 14, 381-392.

622 Nogueira, M. G., Henry, R. \& Maricatto, F. E. (1999). Spatial and temporal heterogeneity in 623 the Jurumirim reservoir, São Paulo, Brazil. Lakes \& Reservoirs: Research \& 624 Management, 4, 107-120.

625 Nogueira, M.G, Pomari, J., Ferreira, R.A.R., Pessotto, M.A. \& Vianna, N. (2014). A represa 626 de Jurumirim como um Sistema espacialmente complexo - limnologia, qualidade de 627 água, comunidade fitoplanctônica em uma abordagem inter-década, in: Henry, R., (Ed.) 628 Represa de Jurumirim: ecologia, modelagem e aspectos sociais. Holos, Ribeirão Preto, 629 SP.

630 Novaes, J.L.C., \& Carvalho, E.D. (2009). Recursos pesqueiros oriundos da pesca artesanal no 631 reservatório de Jurumirim, Rio Paranapanema, Alto Paraná, Brasil. Boletim do Instituto 632 de Pesca, 35, 553-565.

633 O'Sullivan, P. \& Reynolds, C.S. (2008). The lakes handbook: lake restoration and 634 rehabilitation. Wiley-Blackwell. 
635 Oksanen, J., Blanchet, F.G., Kindt, R., Legendre, P., O’Hara, R.B., Simpson, G. L., Solymos, 636 P., Henry, M., Stevens, H. \& Wagner, H. (2015). Vegan: Community Ecology Package. $R$ package version $\mathbf{2}, 0-10$.

Pelicice, F. M. \& Agostinho, A. A. (2009). Fish fauna destruction after the introduction of a non-native predator (Cichla kelberi) in a Neotropical reservoir. Biological Invasions, 11, 1789-1801.

Pianka, E. R. (1966). Latitudinal gradients in species diversity: a review of concepts. The American Naturalist, 100, 33-46.

Reis, R.E., Kullander, S.O. \& Ferraris, C.J. (2003). Check list of the freshwater fishes of South and Central America. Porto Alegre: Edipucrs.

Santos, G.B., Maia-Barbosa, P.M., Vieira, F. \& López, C.M. (1994). Fish and zooplankton community structure in reservoirs of southeastern Brazil: effects of the introduction of exotic predatory fish, in: Pinto-Coelho, R. M., Giani, A., Von Sperling, E. (Eds.) Ecology and Human Impacts on Lakes and Reservoirs in Minas Gerais with Special

Schork, G., Hermes-Silva, S., \& Zaniboni-Filho, E. (2013). Analysis of fishing activity in the Itá reservoir, Upper Uruguay River, in the period 2004-2009. Brazilian Journal of Biology, 73, 559-571.

Stanley, S.M., (1979). Macroevolution, pattern and process. Johns Hopkins University Press. Carpenter, S.R., de Vries, W., de Wit, C.A., Folke, C., Gerten, D., Heinke, J., Mace, 
659 Steneck, R. S., Watling, L. (1982). Feeding Capabilities and Limitation of Herbivorous

660 Molluscs: A Functional Group Approach. Marine Biology, 68(3), 299-319.

661 Suguio, K. \& Suguio, K. (1973). Introdução à sedimentologia. São Paulo: Edgard Blücher 662 Ltda and EDUSP-SP.

663 Teixeira, C., Tundisi, J. \& Kutner, M. B. (1965). Plankton studies in a mangrove environment 664 II: the standing stock and some ecological factors. Boletim do Instituto $665 \quad$ Oceanográfico, 14, 13-41.

666 Thornton, K.W., Kimmel, B.L. \& Payne, F.E., (1990). Reservoir limnology: Ecological 667 perspectives. New York: John Wiley and Sons.

668 Tittensor, D. P., Mora, C., Jetz, W., Lotze, H. K., Ricard, D., Berghe, E. V. \& Worm, B. 669 (2010). Global patterns and predictors of marine biodiversity across taxa. Nature, 466, $670 \quad 1098$.

671 Vanschoenwinkel, B., Waterkeyn, A., Jocqué, M., Boven, L., Seaman, M. \& Brendonck, L. 672 (2010). Species sorting in space and time - the impact of disturbance regime on 673 community assembly in a temporary pool metacommunity. Journal of the North 674 American Benthological Society, 29, 1267-1278.

675 Vitule, J. R. S., Freire, C. A. \& Simberloff, D. (2009). Introduction of non-native freshwater 676 fish can certainly be bad. Fish and Fisheries, 10, 98-108.

677 Wentworth, C. K. (1922). A scale of grade and class terms for clastic sediments. The Journal 678 of Geology, 30, 377-392.

679 Wetzel, R.G. (2001). Limnology: Lake and River Ecosystems. New York: Academic Press. 680 Wickham, H. (2009). ggplot2: elegant graphics for data analysis. Berlim: Springer Science 681 and Business Media. 
682 Williams, J. D., Winemiller, K. O., Taphorn, D. C. \& Balbas, L. (1998). Ecology and status 683 of piscivores in Guri, an oligotrophic tropical reservoir. North American Journal of $684 \quad$ Fisheries Management, 18, 274-285.

685 Zanata, L. H. \& Espíndola, E. L. G. (2002). Longitudinal processes in Salto Grande reservoir 686 (Americana, SP, Brazil) and its influence in the formation of compartment

687 system. Brazilian Journal of Biology, 62, 347-361.

688 Zuur, A., Ieno, E.N., Walker, N., Saveliev, A.A. \& Smith, G.M. (2009). Mixed effects models 689 and extensions in ecology with R. Berlim: Springer Science and Business Media.

690

691

692

SUPPORTING INFORMATION

693

694

695 Additional Supporting Information is found in the online version of this article:

696 Environmental variation analysis include Table S1; List of fish species include Table S2 and

697 Table S3; Confidence intervals of model-average coefficients for interception of random 698 variables in Figure S1.

699

700

701

702

703

704

705

706

707

708 
709 Figure 1. Sampling locations and qualitative description of all sites on Jurumirim Reservoir,

710 Brazil: red arrow indicates the dam of the hydroelectric plant.

711

712 Figure 2. Ordination of fish species composition by Nonmetric Multi-Dimensional Scaling

713 (NMDS) of Bray-Cutis distances $(\mathrm{k}=2$, stress $\approx 10 \%)$. The ordination is based on 31 fish

714 species abundance sampled from 100 observations in the Jurumirim Reservoir, Upper

715 Paranapanema River, São Paulo, Brazil. Fish species are plotted in blue. Confidence ellipses

716 are shown for each group at a confidence interval of $95 \%$. Acronyms for the respective

717 species are represented in Table S2.

718

719 Figure 3. Box-plots of the ratio of biomass (a) and number of individuals (b) to higher and 720 lower trophic groups to each habitat type and over the months. Lower trophic groups $=$

721 herbivores, iliophagous, insectivores; higher trophic groups = piscivores, omnivores,

722 detritivores.

723

724 Figure 4. The interaction effect of explanatory variables (x-axes) for the response variables

725 (y-axes). The range of variables was fixed at four constants to visualize the interactions:

726 black - small, blue - small/mid, purple - mid/large and orange - large values. The interaction

727 values were centered and scaled as all numerically predicted variables.

728

729

730

731

732

733

734 
Figure 1

\begin{tabular}{|cccc|}
\hline Localization & Limnologic aspect & Habitat type & Code \\
Paranapanema & lotic & main channel/ rectilinear margin & ri1 \\
Paranapanema & lotic & main channel / meandering margin & ri2 \\
Sete llhas & lentic & marginal lagoon/circular margin & la1 \\
Poço das Pedras & lentic & marginal lagoon/irregular margin & la2 \\
Jurumirim & lentic & reservoir/upper & re1 \\
Jurumirim & lentic & reservoir/middle & re2 \\
Jurumirim & lentic & reservoir/lower (next to hydrelectric plan) & re3 \\
Taquari & lotic & tributary, rectilinear and shallow margin with forest fragment & ri3 \\
Taquari & lotic & tributary, meandering and deep & ri4 \\
Taquari & lentic & tributary, beginning of the flood plain & re4 \\
Veados & lentic & tributary, meandering and shallow & ri5 \\
Veados & lentic & tributary, beginning of the flood plain & re5 \\
Veados & lentic & tributary, flood plain and wide & re6 \\
\hline
\end{tabular}

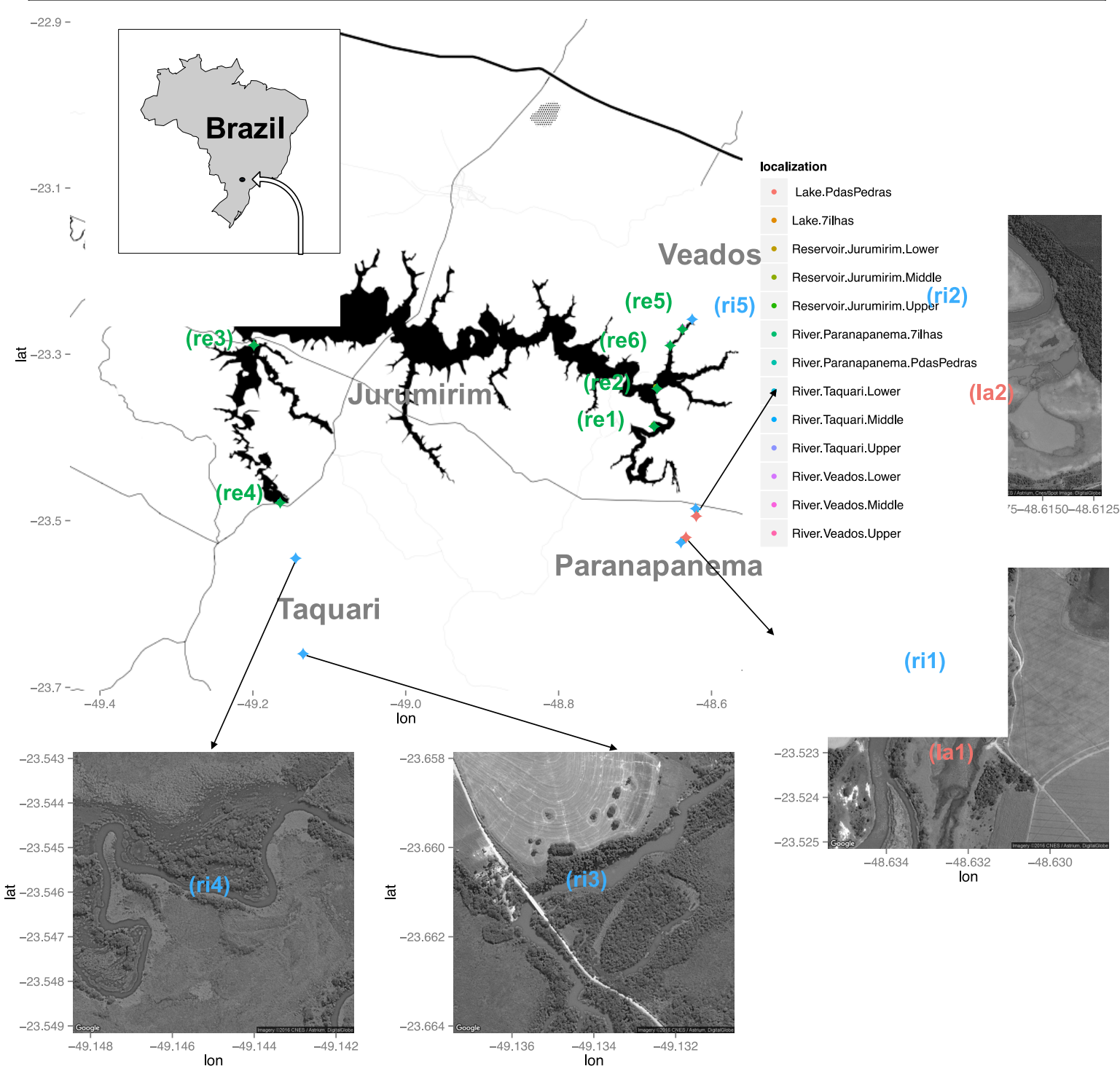


Figure 2

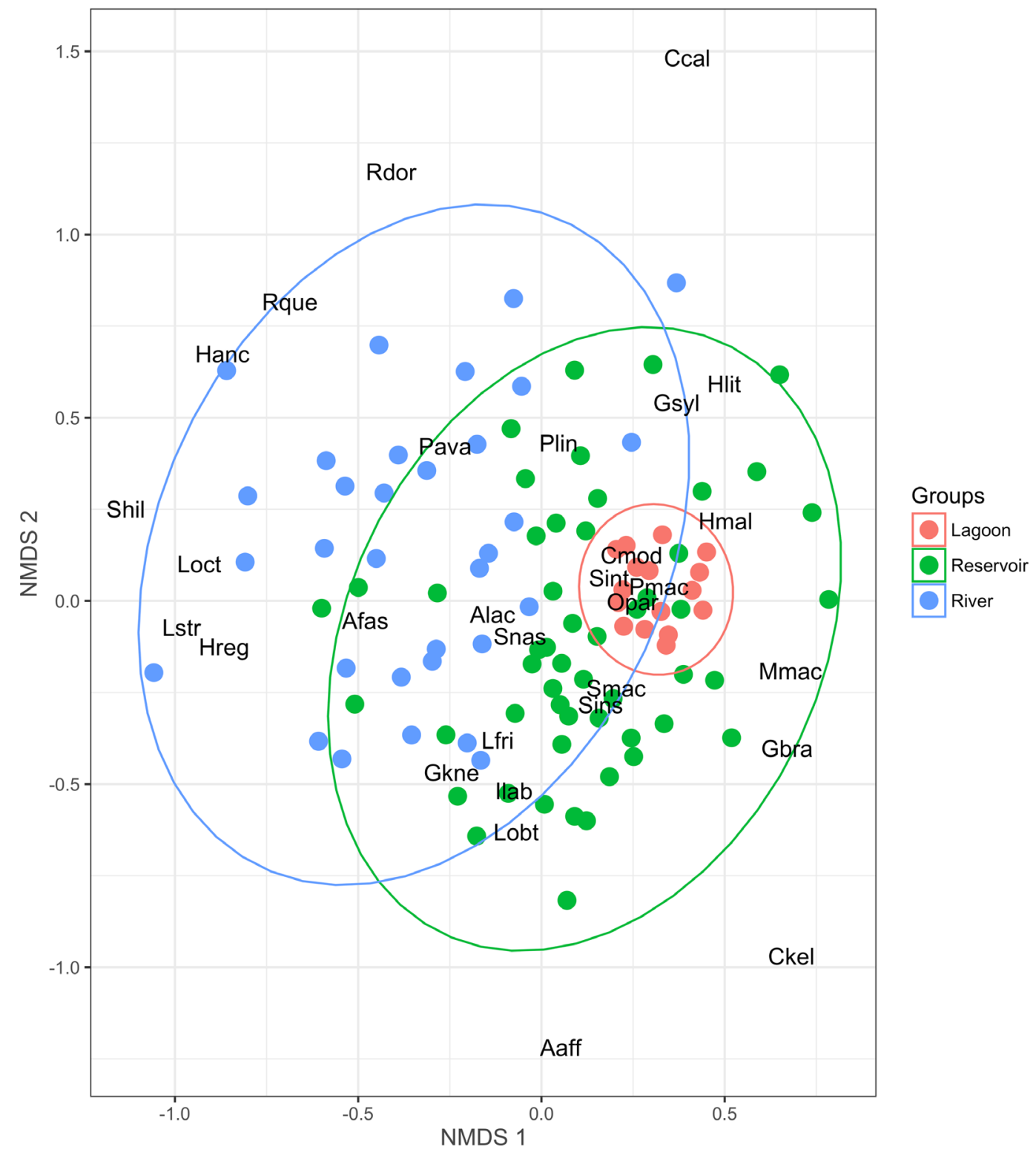


752 Figure 3
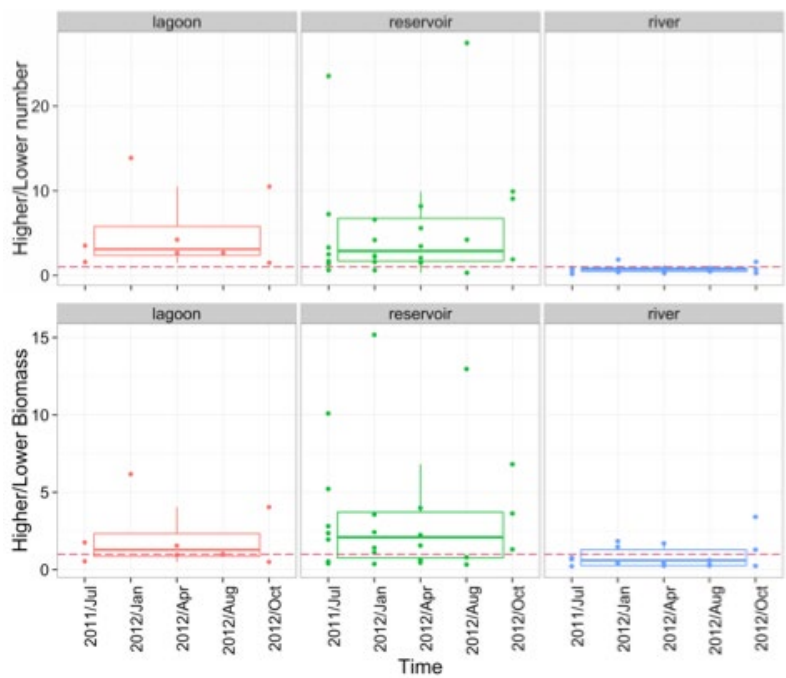

753

754

755

756

757

758

759

760

761

762

763

764

765

766

767

768

769

770

771

772

773 
Figure 4

(a)

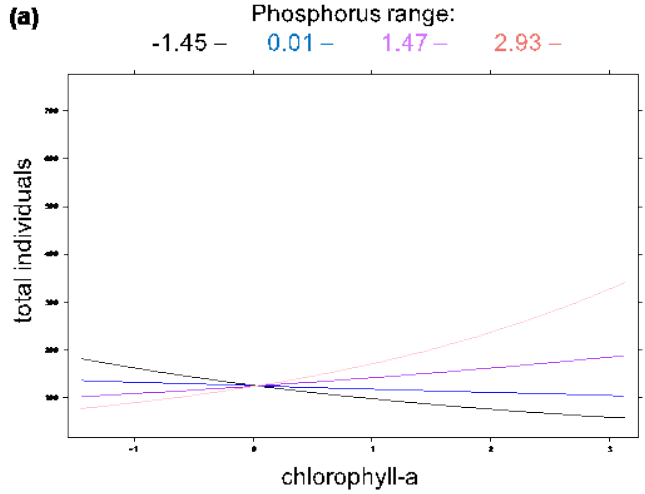

(c)

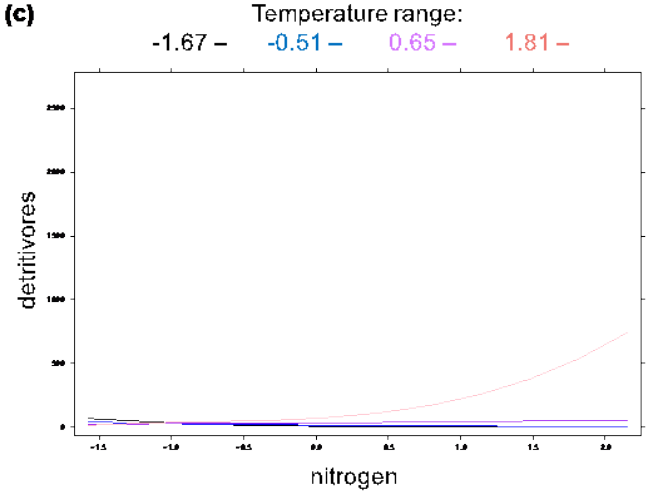

(e)

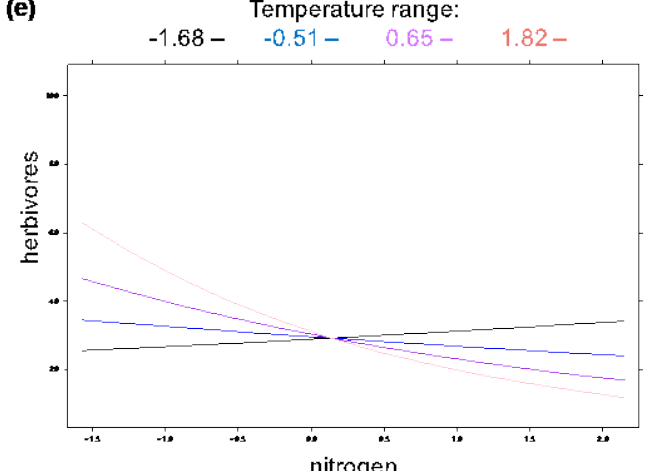

(g)

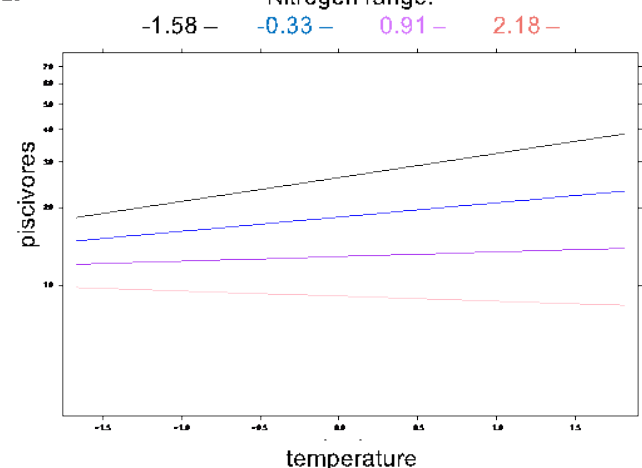

(b) Nitrogen range:

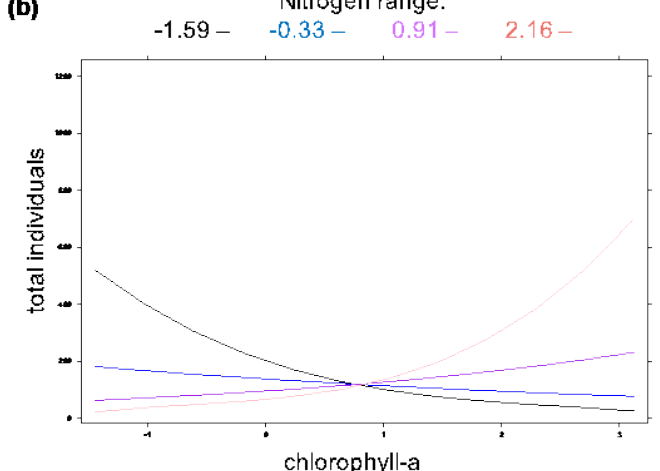

(d)

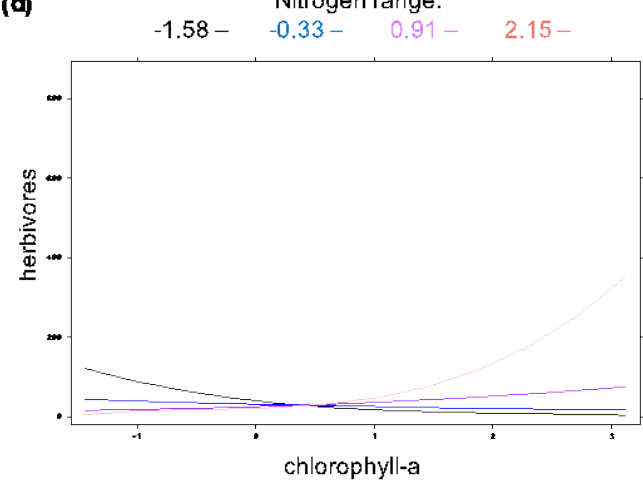

(f)

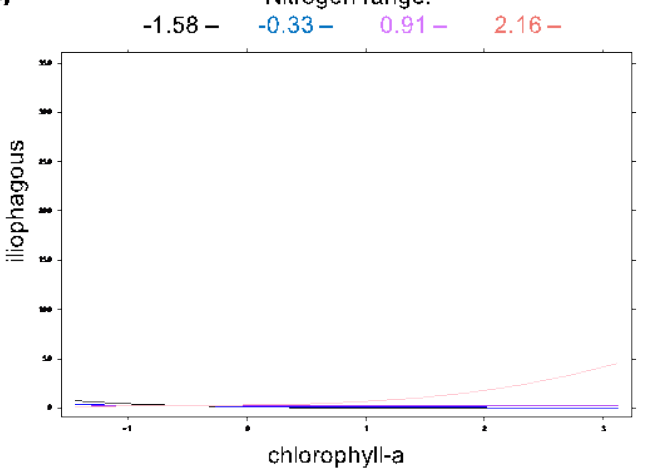

(h)

$-1.58-\quad-0.33-\quad 0.91-2.16-$

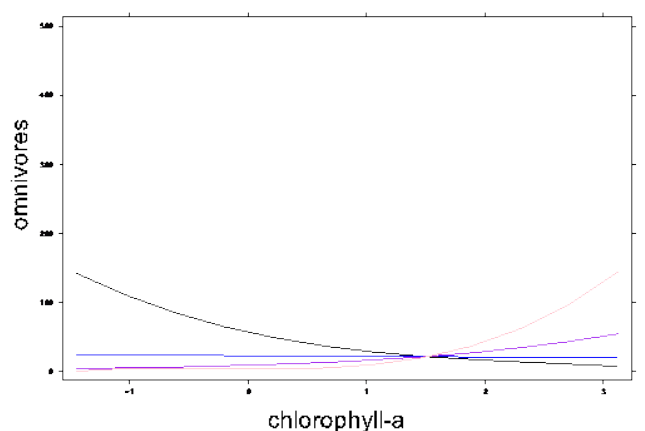

